\title{
Violence against children and adolescents: profile and tendencies resulting from Law 13.010
}

\author{
Violência contra crianças e adolescentes: perfil e tendências decorrentes da Lei no 13.010 \\ Violencia contra niños y adolescentes: perfil y tendencias derivadas de la Ley no 13.010
}

\section{Daniella Fagundes Souto', Luciane Zanin', Glaucia Maria Bovi Ambrosano", Flávia Martão Flório'}

' Faculdade São Leopoldo Mandic, Department of Public Health. Campinas, São Paulo, Brazil. "Faculdade de Odontologia de Piracicaba, Department of Preventive and Social Dentistry. Piracicaba, São Paulo, Brazil.

\section{How to cite this article:}

Souto DF, Zanin L, Ambrosano GMB, Flório FM. Violence against children and adolescents: profile and tendencies resulting from Law 13,010. Rev Bras Enferm [Internet]. 2018;71(Suppl 3):1237-46.

[Thematic Issue: Health of woman and child] DOI: http://dx.doi.org/10.1590/0034-7167-2017-0048

\section{Submission: 03-03-2017 Approval: 07-18-2017}

\section{ABSTRACT}

Objective: Describing the profile of reported violence against children and adolescents and draw an essay on the initial effects of Law 13.010 on report patterns. Method: Analytic study of reported cases on SINAN - Information System on Reportable Harms (from 2013 to 2015) of violence to individuals under 19, in 53 cities of Minas Gerais. Results: 1,481 cases were reported, 49.2\% before and $50.8 \%$ after Law 13.010 came to force $(p=0.5501)$. There was a $7 \%$ decrease on female reports and a $27.2 \%$ in male reports $(p=0.0055)$. It was noticed a change in report patterns $(p=0.0023)$, with a $130.7 \%$ increase to neglect/abandonment reports and a $33 \%$ decrease to sexual abuse report. Higher rates of violence from the parents happens at the 1 to 9-year-old age group ( $p<$ 0.0001). Conclusion: Main victims were women, individuals from 15 to 19 years, with aggression happening within the household; after Law 13.010, changes to patterns of victim and offender profiles and of kind of violence were noticed.

Descriptors: Violence; Child Abuse; Child Health; Adolescent Health; Health Information Systems.

\section{RESUMO}

Objetivo: Descrever o perfil da violência notificada contra crianças e adolescentes e realizar um ensaio sobre os efeitos iniciais da Lei $n^{\circ} 13.010$ no padrão das notificações. Método: Estudo analítico dos casos registrados no SINAN - Sistema de Informação de Agravos de Notificação (2013 a 2015) de violência a menores de 19 anos, em 53 municípios de Minas Gerais. Resultados: Foram notificados 1.481 casos, $49,2 \%$ antes e $50,8 \%$ depois da lei $(p=0,5501)$. Houve uma diminuição das notificações de $7 \%$ no sexo feminino e aumento de $27,2 \%$ no masculino ( $p=0,0055)$. Verificou-se modificação no padrão das notificações $(p=0,0023)$, com o aumento de 130,7\% em negligência/abandono e diminuição de 33\% no abuso sexual. Maior violência por pai e mãe ocorre nas faixas de 1 a 9 anos $(p<0,0001)$. Conclusão: As principais vítimas foram mulheres, indivíduos de 15 a 19 anos, e agressões ocorrendo na residência; nota-se, após a Lei, mudanças no padrão do perfil da vítima e do agressor e no tipo de violência.

Descritores: Violência; Maus-Tratos Infantis; Saúde da Criança; Saúde do Adolescente; Sistemas de Informação em Saúde.

\section{RESUMEN}

Objetivo: Describir el perfil de la violencia notificada contra niños y adolescentes y realizar un ensayo sobre los efectos iniciales de la Ley $n^{\circ} 13.010$ en el patrón de las notificaciones. Método: Estudio analítico de los casos registrados en el SINAN - Sistema de Información de Enfermedades de Declaración Compulsória (2013 a 2015) de violencia a menores de 19 años, en 53 municipios de Minas Gerais. Resultados: Se notificaron 1.481 casos, $49,2 \%$ antes y $50,8 \%$ después de la ley ( $p=0,5501)$. Se observó una disminución de las notificaciones del $7 \%$ en el sexo femenino y un aumento del $27,2 \%$ en el masculino $(p=0,0055)$. Se verificó una modificación en el patrón de las notificaciones ( $p=0,0023)$, con el aumento del 130,7\% en negligencia/abandono y disminución del 33\% en el abuso sexual. La mayor violencia por padre y madre ocurre en las franjas de 1 a 9 años $(p<0,0001)$. Conclusión: Las principales víctimas fueron mujeres, individuos de 15 a 19 años, y agresiones ocurriendo en la residencia; se nota, después de la Ley, cambios en el patrón del perfil de la víctima y del agresor y en el tipo de violencia.

Descriptores: Violencia; Maus-Tratos Infantiles; Salud del Niño; Salud del Adolescente; Sistemas de Información en Salud. 


\section{INTRODUCTION}

Children and adolescents, due to their peculiar development stage, are pointed out as the most vulnerable victims to violence; consequences incurred from such exposure are, oftentimes, irreversible and result in physical and psychological damage, as well as harming growth, development and maturation ${ }^{(1)}$.

Cases of violence against minors happen regardless of race, class, religion or culture ${ }^{(2)}$, although there are socioeconomic, demographic and familial factors associated to a higher risk of child abuse ${ }^{(3-4)}$. In their vast majority, those cases remain silent and silenced within the environment where they happen, with estimates that every day 227 children and teenagers die in the world and, to each death, many more are hospitalized due to wounds ${ }^{(5)}$. Considering data from 190 countries, it is noticeable that one to each three adolescents have already been victims to emotional, physical or sexual violence ${ }^{(6)}$. Brazil locates a fifth of all murders of children and adolescents in the world, besides being the second place with the highest number of murders, seconded only by Nigeria( ${ }^{(7)}$.

In the last decades, acknowledgement of violence as a public health problem in Brazil and of the need to protect children and adolescents, in order to contribute to their growth and development, enlarged policies and strategies aimed at the rising matter of violence within that age group.

Pursuant to the Convention on the Rights of the Child (1989), Brazil was the first country to enact a legal instrument on the matter, the Statute of Children and Adolescents (locally abbreviated to "ECA")(8), sanctioned by Law 8.069/9. It constituted as an instrument of guarantee of citizenship, granting absolute priority to children and adolescents on care and protection against neglect, discrimination, exploitation, violence, cruelty and/or oppression. ECA also created legal obligations to healthcare professionals regarding reports on actions or omissions affection their fundamental rights; it also created the Tutelary Council, an institution responsible for evaluation the reported case, starting the measures to be taken by each specific child protection service.

Following those moves, many more facts happened in Brazil in order to spread the discussion about the issue, aiming to know what is the reality of the violations and enforce programs and measures that can overcome them. In 2010, Constitutional Amendment Bill $n^{\circ} 65$, known as "Youth Amendment", passed in Congress; in 2011, the Second National Youth Conference was made, themed "Youth, development and effectiveness of rights"; in May 2013, the new National Plan for Combating Sexual Abuse Against Children and Adolescents was approved; in August 2013, Law 12.852 was approved, enacting the Statute of Youth and ordaining on the rights of the youth.

More recently, on June 26, 2014, Law 13,010 came to force, also known as "Bernardo's Law" or "Spanking Law". This legal act brought some provisions for handling cases when child or adolescent abuse is noticed, defined the terms "physical punishment" and "cruel treatment", as well as measures to be taken by the Tutelary Council and Government in case abuse is noticed ${ }^{(9)}$. This law was created in order to modify ECA where necessary to ensure higher protection and safety against domestic abuse in general, to establish the right to education and care, free from physical punishment or cruelty or degrading treatment against children and adolescents ${ }^{(10)}$.

This Law was named after the boy Bernardo Uglione Boldrini, who was killed in April 2014, in Rio Grande do Sul, with his father and stepmother as the main suspects, a case which caused vast national commotion.

In that sense, it is herein investigated for the first time whether there has been an alteration in frequency of report numbers, either due to the critical debate about physical punishment used on the educational process or due to the incentive to reports and notification of abuse. In that perspective, this article attempts to describe the profile of reported violence against children and adolescents in cities in the north of Minas Gerais and bring an essay on the initial effects of Law 13,010 to the report pattern.

\section{OBJECTIVE}

Describing the profile of reported abuse against children and adolescents and bring an essay on the initial effects of Law 13,010 to the report pattern.

\section{METHOD}

\section{Ethical aspects}

This study was approved by the Research Ethics Council CEP of Faculdade São Leopoldo Mandic.

\section{Design, location and timeframe}

This is a transversal, analytical and quantitative study, which used data referring to abuse reports in the Information System on Reportable Harms - SINAN, from June 16, 2013 to June 26, 2015.

\section{Population study and inclusion criteria}

This investigation had a population study of children and adolescents under 19 years of age, who have been victims of any sort of abuse reported in SINAN, during the timeframe, and who were residents to one of the 53 cities within the Regional Health Superintendence of Montes Claros (SRS): Berizal, Bocaiúva, Botumirim, Capitão Enéas, Catuti, Claro dos Poções, Coração de Jesus, Cristália, Curral de Dentro, Engenheiro Navarro, Espinosa, Francisco Dumont, Francisco Sá, Fruta de Leite, Gameleiras, Glaucilândia, Grão Mogol, Guaraciama, Indaiabira, Itacambira, Jaíba, Janaúba, Jequitaí, Joaquim Felício, Josenópolis, Juramento, Lagoa dos Patos, Mamonas, Matias Cardoso, Mato Verde, Monte Azul, Montes Claros, Montezuma, Ninheira, Nova Porteirinha, Novorizonte, Olhos-d'Água, Padre Carvalho, Pai Pedro, Porteirinha, Riacho dos Machados, Rio Pardo de Minas, Rubelita, Salinas, Santa Cruz de Salinas, Santo Antônio do Retiro, São João da Lagoa, São João do Pacuí, São João do Paraíso, Serranópolis de Minas, Taiobeiras, Vargem Grande do Rio Pardo and Verdelândia.

\section{Study protocol}

After authorization from SRS, which stores the information from Individual Notification/Investigation Report of Domestic, 
Sexual and/or Other Abuse from cities in the north of Minas Gerais state, data collection and document analysis was made. The searched variables were:

1. In relation to the victim:

- report date;

- marital status (single, married/civil union, widow/er, divorced, inapplicable and unknown);

- gender (male, female);

- age (age groups under 1 year; 1 -4 years; 5-9 years; $10-14$ years; 15-19 years);

- educational background (illiterate, incomplete 1st to 4th grade, complete 4th grade, incomplete 5th to 8th grade, complete Middle School, incomplete High School, complete High School, incomplete Higher Education, Higher Education Graduate, unknown or inapplicable);

2. Incident data:

- city of the report;

- place of the incident (residence, collective dwelling, school, sports practice venue, bar or similar, public street, store/ shop, factory/construction site, another, unknown)

\section{Violence typology}

- kind of violence (physical, psychological/moral, torture, sexual, self-inflicted, accident, intoxication, legal intervention, medication, poisoning, harassment, threat, torture, alcohol abuse, child grooming, human trafficking, firearms, neglect/abandonment, unspecified);

- means of aggression (brute force/spanking, choking, sharp object, hot substance, blunt object, poisoning, firearms, suicide/attempt, other, unspecified);

- in case of sexual abuse, definition as harassment, rape, assault, child pornography, sexual exploitation, other.

4. Probable abuser data:

- ties to the victim (father, mother, stepfather, stepmother, spouse, ex-spouse, boy/girlfriend, ex-boy/girlfriend, son, daughter, brother, sister, friend/acquaintance, stranger, caretaker, employer/boss, person with an institutional relation, police officer/law agent, victim him/herself, other).

5. Evolution and direction: ambulatorial, hospital, inapplicable, unknown, Tutelary Council, Childhood and Adolescence Specialized Court, shelter, Sentinel Program, Child Protection police station, common police station, Public Prosecutor's Office, social reference center/ CREAS-CRAS, legal medical institute, other.

\section{Result analysis and statistics}

Data were organized as to take count of reports 12 months before and 12 months after enactment of Law 13,010 and, initially, analyzed through frequency distribution tables. A chi-square test was also made in order to compare total reports before and after the law. The expected value for this test was $50 \%$ of the sample, i.e., the null hypothesis was that reports would be distributed equally on both periods. After that, chi-square tests or Fisher's exact test were applied to analyze the association between the report time (before or after the law) and the age group, gender, kind and place of abuse. Since variable "ties with the abuser" had cases with more than one answer, the aforementioned tests were applied to each category. For that, the frequency of cases that had an abuser of a certain category was compared to the frequency of all others. In all analysis, a significance level of $5 \%$ was taken into consideration, and the software R Core Team (2015) was used (R: A language and environment for statistical computing. R Foundation for Statistical Computing, Vienna, Austria. URL https://www.R-project.org/.).

\section{RESULTS}

On the study timeframe, as observed on Table 1, 1,481 reports of abuse against children and adolescents were identified, most related to 15 to 19 -year-olds (41.1\%), women $(66.7 \%)$ and having their residence as the main location for abuse (49.6\%). Regarding Law 13,010, 49.2\% (729) cases were reported before its enactment and 50,8\% (752) after it, posing a slight, but not significant $(p=0.5501)$, increase of $3.2 \%$ after the Law.

Analyzing the distribution of reports according to age group, it is observed that, on average, most cases affected 15 to 19-yearold individuals $(41.1 \%)$ and it can be noticed that there has been an association with the enactment of the law ( $p=0.0177)$. For those under 1 year of age and for the age group from 15 to 19 , reports increased, at the same time a decrease of $15 \%$ was observed for reports about children aged 1 to 4 and individuals aged 10 to 14 . Although reports involve mostly the female gen$\operatorname{der}(66.7 \%)$, there was a significant difference of report frequency considering the genders ( $p=0.0055)$, since, after the law was enacted, there was a decrease of $7 \%$ for reports of female victims and an increase of $27.2 \%$ of male victims.

An absence of association was observed between the location of the abuse in the two periods under analysis. The residence was the place where most reported cases happened, although a discreet decrease $(2.9 \%)$ was noticed during the studied timeframe. On the other hand, the highest increases were observed on collective dwellings, sports practice venues and on public streets, second ranking in frequency of reported cases. Among the $30.2 \%$ of reported cases of repeated abuses, $31.5 \%$ happened before the law and $28.9 \%$ after it.

As observed on Table 2, physical abuse showed the highest reporting frequency (63.1\%). Regarding the law, there was an increase on report frequency in 10 out of 18 of recorded kinds of abuse ( $p=0.0023$ ). Out of the four most prevalent kinds, a slight increase in reports of physical and psychological abuse can be noticed, as well as an important increase to reports about neglect/abandonment. There was a $30 \%$ decrease on sexual abuse reports.

Table 3 contains the frequency of reported incidents according to the cities where they were reported. It is noticeable that there was an increase to reporting frequency in $62 \%$ of them. Considering the 10 cities with the highest notification frequency, although for most of them there was a decrease in reporting frequency, in three of them, the increase observed after implementation of the new law was higher than $40 \%$. In $14 \%$ of evaluated cities, report numbers more than doubled after the law. 
Table 1 - Frequency distribution of cases of violence against children and adolescents by age group, place of abuse and repeated abuses, before and after enactment of Law 13,010, in the 53 cities under study, Regional Health Superintendency of Montes Claros - State of Minas Gerais, Brazil (2013-2015)

\begin{tabular}{|c|c|c|c|c|c|}
\hline \multirow{2}{*}{ Variables } & Before the Law & After the Law & Total & \multirow{2}{*}{$\begin{array}{l}\text { Difference between } \\
\text { timeframes }\end{array}$} & \multirow{2}{*}{$p$ value } \\
\hline & & n $(\%)^{\&}$ & & & \\
\hline Age Group & & & & & 0.0177 \\
\hline Under 1 year old & $14(1.9 \%)$ & $21(2.8 \%)$ & $35(2.4 \%)$ & $50.0 \%$ & \\
\hline 1 to 4 years old & $88(12.1 \%)$ & $75(10.0 \%)$ & $163(11.0 \%)$ & $-14.8 \%$ & \\
\hline 5 to 9 years old & $120(16.5 \%)$ & $127(16.9 \%)$ & $247(16.7 \%)$ & $5.8 \%$ & \\
\hline 10 to 14 years old & $233(32.0 \%)$ & $194(25.8 \%)$ & $427(28.8 \%)$ & $-16.8 \%$ & \\
\hline 15 to 19 years old & $274(37.6 \%)$ & $335(44.5 \%)$ & $609(41.1 \%)$ & $29.6 \%$ & \\
\hline Gender & & & & & 0.0055 \\
\hline Female & $512(70.2 \%)$ & $476(63.3 \%)$ & $988(66.7 \%)$ & $-7.0 \%$ & \\
\hline Male & $217(29.8 \%)$ & $276(36.7 \%)$ & $493(33.3 \%)$ & $27.2 \%$ & \\
\hline Place of incident & & & & & 0.4671 \\
\hline Residence & $371(50.9 \%)$ & $364(48.4 \%)$ & $735(49.6 \%)$ & $-2.90 \%$ & \\
\hline Street & $100(13.7 \%)$ & $140(18.6 \%)$ & $240(16.2 \%)$ & $40.00 \%$ & \\
\hline School & $64(8.8 \%)$ & $64(8.5 \%)$ & $128(8.6 \%)$ & $0.00 \%$ & \\
\hline Bar or similar & $19(2.6 \%)$ & $16(2.1 \%)$ & $35(2.4 \%)$ & $-15.80 \%$ & \\
\hline Collective dwelling & $7(0.9 \%)$ & $10(1.3 \%)$ & $17(1.1 \%)$ & $42.80 \%$ & \\
\hline Sports practice venue & $5(0.7 \%)$ & $9(1.2 \%)$ & $14(0.9 \%)$ & $80.00 \%$ & \\
\hline Shop or store & $7(1.0 \%)$ & $4(0.5 \%)$ & $11(0.7 \%)$ & $-42.80 \%$ & \\
\hline Industry or construction site & $3(0.4 \%)$ & $3(0.4 \%)$ & $6(0.4 \%)$ & $0.00 \%$ & \\
\hline Repeated aggressions & & & & & 0.2124 \\
\hline Yes & $216(29.6 \%)$ & $198(26.3 \%)$ & $414(28.0 \%)$ & $-8.3 \%$ & \\
\hline No & $331(45.4 \%)$ & $353(46.9 \%)$ & $684(46.2 \%)$ & $6.6 \%$ & \\
\hline Unknown & $138(18.9 \%)$ & $135(18.0 \%)$ & $273(18.4 \%)$ & $-2.2 \%$ & \\
\hline Total N $(\%)^{\$}$ & $729(49.2 \%)$ & $752(50.8 \%)$ & $1481(100 \%)$ & $3.2 \%$ & \\
\hline
\end{tabular}

Note: ${ }^{\&}$ Relative frequency regarding the sample, in each timeframe, for each variable; ${ }^{\$}$ Relative frequency regarding the total sample.

Tabela 2 - Prevalence of different kinds of violence suffered by children and adolescents, before and after enactment of Law 13,010, in the 53 cities under study, Regional Health Superintendency of Montes Claros - State of Minas Gerais, Brazil (2013-2015)

\begin{tabular}{|c|c|c|c|c|c|}
\hline \multirow{2}{*}{ Kind of Violence } & Before the Law & After the Law & Total & \multirow{2}{*}{$\begin{array}{l}\text { Difference between } \\
\text { timeframes }\end{array}$} & \multirow{2}{*}{$p$ value } \\
\hline & \multicolumn{3}{|c|}{ n $(\%)^{\&}$} & & \\
\hline Physical & $458(62.8 \%)$ & $477(63.4 \%)$ & $935(63.1 \%)$ & $4.10 \%$ & \\
\hline Sexual & $143(19.6 \%)$ & $100(13.3 \%)$ & $243(16.4 \%)$ & $-30.10 \%$ & \\
\hline Psychological & $61(8.4 \%)$ & $67(8.9 \%)$ & $128(8.6 \%)$ & $9.80 \%$ & \\
\hline Neglect/abandonment & $13(1.8 \%)$ & $30(4.0 \%)$ & $43(2.9 \%)$ & $130.80 \%$ & \\
\hline Self-inflicted & $7(1.0 \%)$ & $3(0.4 \%)$ & $10(0.7 \%)$ & $-57.1 \%$ & \\
\hline Accident & $1(0.1 \%)$ & $4(0.5 \%)$ & $5(0.3 \%)$ & $300.00 \%$ & \\
\hline Intoxication & $3(0.4 \%)$ & $0(0.0 \%)$ & $3(0.2 \%)$ & $-300.00 \%$ & \\
\hline Legal intervention & $0(0.0 \%)$ & $2(0.3 \%)$ & $2(0.1 \%)$ & $200.00 \%$ & \\
\hline Medication & $0(0.0 \%)$ & $2(0.3 \%)$ & $2(0.1 \%)$ & $200.00 \%$ & \\
\hline Poisoning & $1(0.1 \%)$ & $1(0.1 \%)$ & $2(0.1 \%)$ & $0.00 \%$ & - \\
\hline Threat & $0(0.0 \%)$ & $1(0.1 \%)$ & $1(0.1 \%)$ & $100.00 \%$ & \\
\hline Harassment & $0(0.0 \%)$ & $1(0.1 \%)$ & $1(0.1 \%)$ & $100.00 \%$ & \\
\hline Torture & $0(0.0 \%)$ & $1(0.1 \%)$ & $1(0.1 \%)$ & $100.00 \%$ & \\
\hline Alcohol abuse & $1(0.1 \%)$ & $0(0.0 \%)$ & $1(0.1 \%)$ & $100.00 \%$ & \\
\hline Child grooming & $1(0.1 \%)$ & $0(0.0 \%)$ & $1(0.1 \%)$ & $-100.00 \%$ & \\
\hline Firearms & $1(0.1 \%)$ & $0(0.0 \%)$ & $1(0.1 \%)$ & $-100.00 \%$ & \\
\hline Human trafficking & $1(0.1 \%)$ & $0(0.0 \%)$ & $1(0.1 \%)$ & $-100.00 \%$ & \\
\hline Unspecified & $38(5.2 \%)$ & $63(8.4 \%)$ & $101(6.8 \%)$ & $65.80 \%$ & \\
\hline Total $\mathrm{n}(\%)^{\$}$ & $729(49.2 \%)$ & $752(50.8 \%)$ & $1481(100 \%)$ & $3.2 \%$ & 0.0023 \\
\hline
\end{tabular}

Note: ${ }^{\&}$ Relative frequency regarding the sample, in each timeframe, for each variable; ${ }^{\circledR}$ Relative frequency regarding the total sample. 
Table 3 - Prevalence of abuse suffered by children and adolescents, according to the reporting city, before and after enactment of Law 13,010, in the 53 cities under study, Regional Health Superintendency of Montes Claros - State of Minas Gerais, Brazil (2013-2015)

\begin{tabular}{|c|c|c|c|c|c|}
\hline \multirow{2}{*}{ Variables } & Before the law & After the law & Total & \multirow{2}{*}{$\begin{array}{l}\text { Difference between } \\
\text { timeframes }\end{array}$} & \multirow{2}{*}{$p$ value } \\
\hline & & n $(\%)^{\alpha}$ & & & \\
\hline \multicolumn{6}{|l|}{ City of the Report } \\
\hline Montes Claros & $147(20.2 \%)$ & $111(7.5 \%)$ & $258(17.4 \%)$ & $-24.5 \%$ & -- \\
\hline Bocaiúva & $67(9.2 \%)$ & $114(7.7 \%)$ & $181(12.2 \%)$ & $70.1 \%$ & \\
\hline Matias Cardoso & $42(5.8 \%)$ & $25(1.7 \%)$ & $67(4.5 \%)$ & $-40.5 \%$ & \\
\hline Janaúba & $39(5.3 \%)$ & $23(1.6 \%)$ & $62(4.2 \%)$ & $-41.0 \%$ & \\
\hline Taiobeiras & $31(4.3 \%)$ & $25(1.7 \%)$ & $56(3.8 \%)$ & $-19.4 \%$ & \\
\hline Francisco Sá & $21(2.9 \%)$ & $23(1.6 \%)$ & $44(3.0 \%)$ & $9.5 \%$ & \\
\hline Jaíba & $10(1.4 \%)$ & $29(2.0 \%)$ & $39(2.6 \%)$ & $190.0 \%$ & \\
\hline Grão Mogol & $15(2.1 \%)$ & $21(1.4 \%)$ & $36(2.4 \%)$ & $40.0 \%$ & \\
\hline Coração de Jesus & $19(2.6 \%)$ & $16(1.1 \%)$ & $35(2.4 \%)$ & $-15.8 \%$ & \\
\hline Engenheiro Navarro & $18(2.5 \%)$ & $16(1.1 \%)$ & $34(2.3 \%)$ & $-11.1 \%$ & \\
\hline Porteirinha & $14(1.9 \%)$ & $17(1.1 \%)$ & $31(2.1 \%)$ & $21.4 \%$ & \\
\hline Vardelândia & $15(2.1 \%)$ & $15(1.0 \%)$ & $30(2.0 \%)$ & $0.0 \%$ & \\
\hline Espinosa & $5(0.7 \%)$ & $19(1.3 \%)$ & $24(1.6 \%)$ & $280.0 \%$ & \\
\hline Cristália & $7(1.0 \%)$ & $16(1.1 \%)$ & $23(1.6 \%)$ & $128.6 \%$ & \\
\hline Curral de Dentro & $5(0.7 \%)$ & $17(1.1 \%)$ & $22(1.5 \%)$ & $240.0 \%$ & \\
\hline Nova Porteirinha & $14(1.9 \%)$ & $7(0.7 \%)$ & $21(1.4 \%)$ & $-50.0 \%$ & \\
\hline Rio Pardo de Minas & $6(0.8 \%)$ & $15(1.1 \%)$ & $21(1.4 \%)$ & $150.0 \%$ & \\
\hline Santo Antônio do Retiro & $9(1.2 \%)$ & $12(0.8 \%)$ & $21(1.4 \%)$ & $33.3 \%$ & \\
\hline Ninheira & $9(1.2 \%)$ & $11(0.7 \%)$ & $20(1.4 \%)$ & $22.2 \%$ & \\
\hline Rubelitas & $16(2.2 \%)$ & $3(0.2 \%)$ & $19(1.3 \%)$ & $-81.3 \%$ & \\
\hline São João do Paraíso & $8(1.1 \%)$ & $11(0.7 \%)$ & $19(1.3 \%)$ & $37.5 \%$ & \\
\hline Capitão Enéas & $7(1.0 \%)$ & $10(0.7 \%)$ & $17(1.1 \%)$ & $42.9 \%$ & \\
\hline Montezuma & $10(1.4 \%)$ & $7(0.5 \%)$ & $17(1.1 \%)$ & $-30.0 \%$ & \\
\hline Francisco Dumond & $7(1.0 \%)$ & $9(0.6 \%)$ & $16(1.1 \%)$ & $28.6 \%$ & \\
\hline Pai Pedro & $9(1.2 \%)$ & $7(1.5 \%)$ & $16(1.1 \%)$ & $-22.2 \%$ & \\
\hline Monte Azul & $8(1.1 \%)$ & $7(0.5 \%)$ & $15(1.0 \%)$ & $-12.5 \%$ & \\
\hline Botumirim & $6(0.8 \%)$ & $8(0.5 \%)$ & $14(0.9 \%)$ & $33.3 \%$ & \\
\hline Indaiabira & $4(0.5 \%)$ & $10(0.7 \%)$ & $14(0.9 \%)$ & $150.0 \%$ & \\
\hline São João do Pacuí & $8(1.1 \%)$ & $6(0.4 \%)$ & $14(0.9 \%)$ & $-25.0 \%$ & \\
\hline Josenópolis & $10(1.4 \%)$ & $3(0.2 \%)$ & $13(0.9 \%)$ & $-70.0 \%$ & \\
\hline Mato Verde & $6(0.8 \%)$ & $6(0.4 \%)$ & $12(0.8 \%)$ & $0.0 \%$ & \\
\hline Joaquim Felício & $6(0.8 \%)$ & $5(0.3 \%)$ & $11(0.7 \%)$ & $-16.7 \%$ & \\
\hline Guaraciama & $6(0.8 \%)$ & $4(0.3 \%)$ & $10(0.7 \%)$ & $-33.3 \%$ & \\
\hline Olhos d'Água & $8(1.1 \%)$ & $2(0.1 \%)$ & $10(0.7 \%)$ & $-75.0 \%$ & \\
\hline Riacho dos Machados & $3(0.4 \%)$ & $6(0.4 \%)$ & $9(0.6 \%)$ & $100.0 \%$ & \\
\hline Gameleiras & $4(0.5 \%)$ & $4(0.3 \%)$ & $8(0.5 \%)$ & $0.0 \%$ & \\
\hline Jequitaí & $5(0.7 \%)$ & $3(0.2 \%)$ & $8(0.5 \%)$ & $-40.0 \%$ & \\
\hline Novorizonte & $2(0.3 \%)$ & $6(0.4 \%)$ & $8(0.5 \%)$ & $200.0 \%$ & \\
\hline Juramento & $2(0.3 \%)$ & $5(0.3 \%)$ & $7(0.5 \%)$ & $150.0 \%$ & \\
\hline Mamonas & $3(0.4 \%)$ & $4(0.3 \%)$ & $7(0.5 \%)$ & $33.3 \%$ & \\
\hline Salinas & $1(0.1 \%)$ & $6(0.4 \%)$ & $7(0.5 \%)$ & $500.0 \%$ & \\
\hline Vargem Grande do Rio Pardo & $5(0.7 \%)$ & $2(0.1 \%)$ & $7(0.5 \%)$ & $-60.0 \%$ & \\
\hline Catuti & $1(0.1 \%)$ & $5(0.3 \%)$ & $6(0.4 \%)$ & $400.0 \%$ & \\
\hline Claro dos Poções & $3(0.4 \%)$ & $3(0.2 \%)$ & $6(0.4 \%)$ & $0.0 \%$ & \\
\hline Glaucilândia & $4(0.5 \%)$ & $2(0.1 \%)$ & $6(0.4 \%)$ & $-50.0 \%$ & \\
\hline Berizal & $0(0.0 \%)$ & $5(0.7 \%)$ & $5(0.3 \%)$ & - & \\
\hline Serranópolis de Minas & $2(0.3 \%)$ & $3(0.2 \%)$ & $5(0.3 \%)$ & $50.0 \%$ & \\
\hline Itacambira & $2(0.3 \%)$ & $2(0.1 \%)$ & $4(0.3 \%)$ & $0.0 \%$ & \\
\hline Lagoa dos Patos & $0(0.0 \%)$ & $4(0.3 \%)$ & $4(0.3 \%)$ & - & \\
\hline Padre Carvalho & $4(0.5 \%)$ & $0(0.0 \%)$ & $4(0.3 \%)$ & $-100.0 \%$ & \\
\hline Fruta de Leite & $1(0.1 \%)$ & $2(0.1 \%)$ & $3(0.2 \%)$ & $100.0 \%$ & \\
\hline São João da Lagoa & $1(0.1 \%)$ & $1(0.1 \%)$ & $2(0.1 \%)$ & $0.0 \%$ & \\
\hline Not informed & $74(10.2 \%)$ & $59(7.8 \%)$ & $133(9.0 \%)$ & $-20.3 \%$ & \\
\hline Total N $(\%)^{\$}$ & $729(49.2 \%)$ & $752(50.8 \%)$ & $1481(100 \%)$ & $3.2 \%$ & 0.5501 \\
\hline
\end{tabular}

Note: ${ }^{\circledR}$ Percentage regarding the sample in each timeframe; ${ }^{\$}$ Relative frequency regarding the total sample. 
On Table 4, in can be observed that, regarding the aggressor, the highest frequency of reported incidents involved friends, followed by strangers, father and mother. Considering the evaluated timeframes, there was a significative alteration only regarding strangers, with a decrease of $17.8 \%$ in cases $(p=0.0404)$ and a $100 \%$ increase on reports involving siblings ( $p=0.0237)$. Analyzing the aggressor according to age group, the most mentioned kind was the spouse, responsible for $28.1 \%$ of violence to victims aged under 1 year. For age groups aged 1 to 4 years and 5 to 9 years respectively, father $(21.6 \%$ and $22.2 \%)$ and mother (23.0\% and $14.2 \%)$ appear. However, from 5-years-old onwards, friends were the most mentioned aggressors (5 to 9 years: $32.1 \%$; 10 to 14 years: $39.5 \%$; 10 to 14 years: $30.4 \%$ and 15 to 19 years: $31.9 \%$ (data not presented).

It is observed, regarding sexual violence, there was a prevalence of rape and harassment, with significant decrease, after law enactment, to report numbers for all specified types of abuse. the highest frequency of abuse incidents, analyzed by area, happened in urban zones. Brute force (spanking) was mentioned in most incidents.

Table 4 - Frequency distribution of violence suffered by children and adolescents in relation to ties with the aggressor, kind of sexual violence, area and means of aggression, before and after enactment of Law 13,010, in the 53 cities under study

\begin{tabular}{|c|c|c|c|c|c|}
\hline \multirow{2}{*}{ Variables } & Before the law & After the law & Total & \multirow{2}{*}{$\begin{array}{l}\text { Difference between } \\
\text { timeframes }\end{array}$} & \multirow{2}{*}{$p$ value } \\
\hline & & $N(\& \%)$ & & & \\
\hline \multicolumn{6}{|l|}{ Relation to the aggressor } \\
\hline Friends & $196(26.9 \%)$ & $218(29.0 \%)$ & $414(28.0 \%)$ & $11.20 \%$ & 0.6901 \\
\hline Stranger & $101(13.8 \%)$ & $83(11.0 \%)$ & $184(12.4 \%)$ & $-17.80 \%$ & 0.0404 \\
\hline Father & $69(9.5 \%)$ & $87(11.6 \%)$ & $156(10.5 \%)$ & $26.10 \%$ & 0.3588 \\
\hline Mother & $54(7.4 \%)$ & $64(8.5 \%)$ & $118(8.8 \%)$ & $18.50 \%$ & 0.6257 \\
\hline Spouse & $38(5.2 \%)$ & $30(4.0 \%)$ & $68(4.6 \%)$ & $-21.00 \%$ & 0.1645 \\
\hline Himself & $31(4.2 \%)$ & $36(4.8 \%)$ & $67(4.5 \%)$ & $16.10 \%$ & 0.8329 \\
\hline Stepfather & $39(5.4 \%)$ & $27(3.6 \%)$ & $66(4.5 \%)$ & $-30.80 \%$ & 0.0578 \\
\hline Brother & $20(2.7 \%)$ & $40(5.3 \%)$ & $60(4.0 \%)$ & $100.00 \%$ & 0.0237 \\
\hline Boyfriend & $31(4.25)$ & $23(3.15)$ & $54(3.6 \%)$ & $-25.80 \%$ & 0.1528 \\
\hline Ex-boyfriend & $9(1.2 \%)$ & $11(1.5 \%)$ & $20(1.4 \%)$ & $22.20 \%$ & 0.8108 \\
\hline Ex-spouse & $7(1.0 \%)$ & $7(0.9 \%)$ & $14(1.0 \%)$ & $0.00 \%$ & 0.8618 \\
\hline Son & $8(1.1 \%)$ & $6(0.8 \%)$ & $14(1.0 \%)$ & $25.00 \%$ & 0.4766 \\
\hline Police officer & $6(0.8 \%)$ & $8(1.1 \%)$ & $14(1.0 \%)$ & $-16.10 \%$ & 0.7227 \\
\hline Institution & $8(1.1 \%)$ & $5(0.7 \%)$ & $13(0.9 \%)$ & $37.50 \%$ & 0.3064 \\
\hline Caretaker & $7(1.0 \%)$ & $2(0.3 \%)$ & $9(0.6 \%)$ & $-71.40 \%$ & 0.0950 \\
\hline Emplyer & $1(0.1 \%)$ & $3(0.4 \%)$ & $4(0.3 \%)$ & $200.00 \%$ & 0.6261 \\
\hline Other & $67(9.2 \%)$ & $60(8.0 \%)$ & $127(8.6 \%)$ & $-10.40 \%$ & 0.1566 \\
\hline \multicolumn{6}{|l|}{ Kind of sexual abuse } \\
\hline Rape & $138(96.5 \%)$ & $100(100.0 \%)$ & $238(97.9 \%)$ & $-27.5 \%$ & $<0.0001$ \\
\hline Harassment & $103(72.0 \%)$ & $68(68.0 \%)$ & $171(70.4 \%)$ & $-34.0 \%$ & $<0.0001$ \\
\hline Sexual assault & $55(38.5 \%)$ & $13(13.0 \%)$ & $68(28.0 \%)$ & $-76.4 \%$ & $<0.0001$ \\
\hline Exploitation & $31(21.7 \%)$ & $11(11.0 \%)$ & $42(17.3 \%)$ & $-64.5 \%$ & 0.0013 \\
\hline Child Pornography & $29(20.3 \%)$ & $8(8.0 \%)$ & $37(15.2 \%)$ & $-72.4 \%$ & $<0.0001$ \\
\hline Other & $1(0.7 \%)$ & $10(10.0 \%)$ & $11(4.5 \%)$ & $900.0 \%$ & 0.0248 \\
\hline Area & & & & & 0.6792 \\
\hline Urban & $488(66.9 \%)$ & $488(64.9 \%)$ & $976(65.9 \%)$ & $0.0 \%$ & \\
\hline Rural & $162(22.2 \%)$ & $174(23.1 \%)$ & $336(22.7 \%)$ & $7.4 \%$ & \\
\hline Peri-urban & $6(0.8 \%)$ & $3(0.4 \%)$ & $9(0.6 \%)$ & $-50.0 \%$ & \\
\hline Unanswered & $73(10.0 \%)$ & $87(11.7 \%)$ & $160(10.8 \%)$ & $19.2 \%$ & \\
\hline Means & & & & & 0.3042 \\
\hline Brute force & $379(52.0 \%)$ & $362(48.1 \%)$ & $741(50.0 \%)$ & -4.5 & \\
\hline Firearms & $54(7.4 \%)$ & $74(9.8 \%)$ & $128(8.6 \%)$ & 37.0 & \\
\hline Sharp object & $35(4.8 \%)$ & $48(6.4 \%)$ & $83(5.6 \%)$ & 37.1 & \\
\hline Poisining & $19(2.6 \%)$ & $19(2.5 \%)$ & $38(2.6 \%)$ & 0.0 & \\
\hline Blunt object & $19(2.6 \%)$ & $15(2.0 \%)$ & $34(2.3 \%)$ & -21.1 & \\
\hline Choking & $2(0.3 \%)$ & $6(0.8 \%)$ & $8(0.5 \%)$ & 200.0 & \\
\hline Hot substance & $4(0.6 \%)$ & $3(0.4 \%)$ & $7(0.5 \%)$ & -25.0 & \\
\hline Suicide or attempt & $1(0.1 \%)$ & $0(0.0 \%)$ & $1(0.1 \%)$ & -100.0 & \\
\hline Other & $42(5.8 \%)$ & $55(7.3 \%)$ & $97(6.5 \%)$ & 31.0 & \\
\hline Unspecified & $174(23.9 \%)$ & $170(22.6 \%)$ & $344(23.2 \%)$ & -2.3 & \\
\hline
\end{tabular}

Note: \&Percentage regarding the sample in each timeframe. 
Concerning the origin of the reports, $42 \%$ of them were made by health services and $27.8 \%$ by Tutelary Councils. Common police stations appear at $15.1 \%$ of reports (data not presented).

\section{DISCUSSION}

Data herein presented are pioneering and reflect the efforts of recent legislation, whose goal is to fight abuse against children and adolescents. The "Spanking Law", despite being recent, doesn't bring drastic changes to the rules previously determined in ECA, however, it tries to bring awareness that it is not necessary to use physical violence in order to educate, trying to deal with a cultural matter, which involves the use of physical punishment in this context.

A discreet, but not significant, increase in abuse reports was observed after enactment of Law 13,010, thus being necessary to reflect upon that finding. A study about domestic, sexual and other kinds of abuse perpetrated against children aged 0 to 9 years in Brazil ${ }^{(11)}$ made evident that Minas Gerais is the 15th Brazilian state with the lowest frequency of abuse reports $(11.6 \%)$ in relation to all age groups. It was also verified that few cities in the country reported abuse to SINAN ${ }^{(11)}$. Thus, the increase herein identified is still pale and points to a series of hindrances to be overcome in order to stimulate reporting, despite the government's implementation of legal protective measures in such situations of violence, making reports mandatory even in cases of suspicion ${ }^{(12-13)}$.

In Australia, the number of reports of abuse against children and adolescents has been increasing and the reported gata improved the treatment of the matter in its quality, considering that, in case abuse or neglect is identified, families are investigated and, many times, coercive action is taken ${ }^{(14)}$. The United States of America (USA) are noteworthy for their pioneering public action regulation for combating child abuse $\mathrm{e}^{(15)}$. Compared to those countries, in Brazil, the implementation of a single report file shows the government's effort in a standard characterization of abuse cases. Furthermore, let it be noted political specificities of Brazil in the direction and attention to cases, since, in the USA, abuse records are tied to security services, whereas in Brazil health services are responsible for its scaling and monitoring. Nevertheless, in spite of this favorable context, the practice of reporting confirmed or suspected cases of abuse still presents weaknesses in Brazil ${ }^{(11,15-16)}$.

Among the hindrances in the reporting process, the lack of information of professionals regarding both ECA and the reporting flux and instruments stands out, besides a lack of technical and emotional preparation of professionals to identify abuse, risk situations and warning signs; the fear retaliation by the family, the aggressor and/or the community; and the lack of backup to the protection services, especially concerning the Tutelary Council ${ }^{(15)}$.

Established by health services, the compulsory violence report must be understood as a tool to guarantee the rights and social protection of children and adolescents, since it allows healthcare professionals, as well as educators, social assistants, Tutelary Councils and courts, to take caring measures for abuse victims $^{(11)}$. Reporting means sharing with many areas of society the responsibility of protecting the young. Moreover, in a vigilance context, compulsory violence reporting has as a principle the immediate use of the information in the place it was generated, besides filling national data banks, allowing analysis to guide the planning and employment of actions ${ }^{(11,15-17)}$.

Just as important as identifying the kinds of violence is to be able to discern which gender suffers more with abuse, since the conduction of professional action must be done respection the individuality of each case. The present study showed a decrease in reporting frequency of abuse against females and an increase to males, what has also been verified in other investigations ${ }^{(18-19)}$. On most studies, there is a prevalence of males among victims of violence $\mathrm{e}^{(1,4,11,20)}$, and the means abuse differ according to the gender, with "lack of parental control" being the most frequent one for boys. On the other hand, girls live other two forms of violence: physical and sexual ${ }^{(20)}$.

This study showed that the victim's residence and the street stand out, on reports, as the main locations where violence happens, what is also verified in other studies ${ }^{(13,16-18)}$. The presence of home as a place of violent episodes reveals that abusers belong to the family or have free access to the residence and that both victims and aggressors tend to spend most of the day at home. Furthermore, the abuser supposedly counts on the complicity of one or other members of the family or, even yet, for not taking on the child as his or her own, the abuser establishes a posture of non-commitment with the victim ${ }^{(13)}$. This sort of violence clashes with the idea that home is a safe place, that serves as a source of growth and development for children and adolescents ${ }^{(12)}$. Among the latter, the streets were the main place for violent acts, what shows that, as they grow up, there is exposure to new kinds of violence, which include interpersonal violence outside the family and delinquency ${ }^{(21)}$.

Another important aspect refers to the reports involving repeated abuse, whose rates draws a lot of attention in this research and in previous studies ${ }^{(11,18)}$. It indicates there is continuity to the abuse suffered by a large part of the victims and that repeated aggressions are not isolated events, but a long-term experience.

It was noticed that physical violence presents the largest quantity of reported cases, followed by sexual and psychological abuse and neglect/abandonment. The predominance of physical violence was also made clear in studies made in the state of São Paulo ${ }^{(18)}$, state of Amazonas ${ }^{(19)}$ and in the city of Araçatuba-SP(13). However, in other studies, there was a predominance in cases of sexual abuse $\mathrm{i}^{(16,24)}$ and of neglect/ abandonment ${ }^{(11-12,17,21)}$. A possible explanation for the high number of physical violence reports is the fact that, besides being motivated by social difficulties and a lack of emotional control $^{(12)}$, this kind of violence is oftentimes considered a form of education, as the caretaker/aggressor sees it. Physical violence is, doubtlessly, easier to recognize, what emphasizes the relevance of healthcare professionals detecting and reporting confirmed or suspected cases to the competent authorities ${ }^{(13)}$. Given its high prevalence, it is recommended that diagnosis for abuse be part of examination routine of children and adolescents ${ }^{(18)}$, especially in Basic Healthcare Services, on appointments for monitoring child growth and development and adolescent health. 
Concerning sexual violence, the sexually abusive relationship is a power one between the adult aggressor and the victimized child $^{(12,24)}$. Currently, this abuse is acknowledged as a serious public health problem, requiring preparation both healthcare professionals and institutions to act alongside the young population. When it happens in an intra-family context, it disrupts the social belief on harmonious family life, based on respect and love from father and mother. Thus, a sexually abused child or adolescent may start to maintain conflictual sexual relations with anyone who represents authority and power roles to him or her ${ }^{(16,19)}$. Moreover, there is the lack of preparation and the insensitivity of some professionals tending to victims, whether be it in police stations, hospitals, or Tutelary Councils ${ }^{(16)}$. Therefore, it is shown a growing need to train professionals so as to allow them to grasp real understanding of cases and make adequate interventions ${ }^{(19,21,25)}$.

Abuse typified as neglect/abandonment requires multiprofessional efforts for its identification, considering its singularities. It is a form of abuse of difficult definition, because it involves cultural, social and economic aspects of each family or social group; it is common among children and adolescents ${ }^{(11-12,24)}$. It harms well-being, physical and psychological integrity, freedom and human development ${ }^{(11,26)}$.

Regarding the ties with the aggressor, it was identified that the highest frequency of reports involves friends, followed by strangers, the father and the mother. However, in other investigations, stranges, besides the parents, were those who were among the main aggressors. It is important to highlight that, in those studies ${ }^{(11-13,17-19,21)}$, the predominant age group in focus was of children and, in the present study, the predominant age group was aged 15 to 19 years, what could justify the fact that friends have been the most prevalent kind of aggressor.

Whenever violence is committed by a family member, on the difficulties to face is the fear, mainly by the victim him/herself, of telling about the incident, afraid of punishment. This difficulty goes from diagnosis and reporting to a lack of standard and effective devices for the adequate direction of such cases by the health system ${ }^{(12,24)}$. Therefore, it is evident that parents are among the main perpetrators of violence against children and adolescents, especially among victims aged 5 years or less, where mothers stand out as the main aggressors $^{(12)}$, since they are physically closer to their children.

Regarding the fact that violence against children and adolescents was committed mainly by friends, it is worth mentioning this relationship belongs to the context of extra-familial violence, which must also have its importance duly acknowledged. Usually, social relations with the other members of a community are open, what may favor the emergence of violent episodes, since trust bonds are made with neighbors, friends or other people with no family relation. Thus, mainly, when violence cases are extra-familial, they are committed by someone who is known and trusted ${ }^{(12,23)}$.

By categorizing the reports involving sexual violence in this study, it was evidenced that $97.9 \%$ of victims were raped, $70.4 \%$ were harassed and $28 \%$ were sexually assaulted. In the national panorama this information is confirmed, since approximately $59 \%$ of minors tended by health services were raped and $15.1 \%$ were sexually assaulted ${ }^{(27)}$.
The highest frequency of incidents in urban areas calls for reflection upon the social and cultural contexts which allow violent practices in their midst. The community where violence victims live, the characteristics of schools and work environments, the disorganized or unplanned physical space all present themselves as factors that may fuel violence ${ }^{(19,28)}$.

According to State of the World's Children report ${ }^{(6)}$, more than $50 \%$ of the world's population - including more than a billion children and adolescents - live in urban zones, and to a large number of them, access to health, education, recreation, and basic life condition services is denied. If to those risk factors individual aspects are added, such as a background of violence, substance consumption (tobacco, drugs and alcohol), problems such as poverty or economic instability, social factors such as unstable neighborhoods, and even cultural factors that validate and accept violence, the potential for violent relationships is conformed ${ }^{(6,19)}$.

Brute force or spanking, followed by use of firearms and sharp objects, were the main means of aggression identified in his study and in another one of national scope ${ }^{(11)}$. Such means may result in physical and psychological damage; damage to growth, development and maturing of children, and, usually, those effects can barely be measured, resulting in irreversible harm to those children, besides remaining silent and silenced inside their families, schools, communities and health services ${ }^{(1)}$.

The evolution and directioning of victims of violence in their childhood and adolescence were made mainly to Health Services and to Tutelary Councils, as also previously observed ${ }^{(11,29)}$. Let it be highlighted that early contact to healthcare services is essential to promote better assistance quality and that a quick and effective approach is fundamental for appropriate dealing with this issue.

In order to expand connections with different institutions and authorities, it is required that healthcare professionals, among others, get closer to this reality and acknowledge the available services in their area, whether they are state- or community-organized, and also engage with the mediation of those connections. It is necessary that some services of specific character be implemented, such as systematic campaigns about the protection of children's and adolescents' rights; new mappings of risk zones; improvements to police stations; better multiprofessional assistance to act upon those cases; actions in schools for identifying victims; and promotion of actions that take these public measures from speeches alone and bring them to reality. Nevertheless, it is necessary that what existing protection network we have strengthen the communication mechanisms among its members and acknowledge its place ${ }^{(31)}$.

Law 13,010 does not criminalize parents for educating their children, but sets limits for them not to be abusive. It is one of the actions enforced by government with the intention of educating people to solve their problems through dialog instead of physical aggression and/or humiliation.

\section{Study limitations}

It is not intended, through this research, to exhaust the discussion related to the profile of violence against children and adolescents in the cities under study, since, as a limitation, this study did not cover data from Sentinel Program nor from Disk 100 (human rights violations anonymous complaint channel), 
which were established in different dates in each city. Furthermore, though the evaluation timeframe may seem insufficient to analyze changes resulting from the law, this should be understood as an initial outlook for new research, since Law 13,010 is still considered new in the legal system, opening space for new reflections and debates about this topic. Thus, it is understood that, even with its limitations, it is necessary to persist in the acknowledging the frequency of this phenomenon in our societies, based on available data.

\section{Contributions to the nursing area}

With the shielding provided by children and adolescent protection laws, it is possible to reflect more responsibly about the means to help and protect them in a safer and more effective way. It becomes, therefore, indispensable the epidemiologic treatment of aggression to children and adolescents, in order to reach an understanding and scaling of this problem, as well as to allow the elaboration of articulate, interdisciplinary and intersectoral action for its local combat, looking for control, prevention and effective assistance measures.

\section{CONCLUSION}

In the study timeframe, the highest reporting frequency of violence cases involved women, individuals aged between 15 and 19 years, physical aggression situations, incidents in urban areas and inside the victims' residences. Regarding the law, always considering it is still considered new in the legal system, the present study did not identify alterations on the frequency od reports and complains about abuse against children and adolescents in the 53 cities under study in the state of Minas Gerais, yet it identified changes by analyzing age group, gender, kinds of violence and aggressor. Hopefully these findings can not only encourage reporting, but also contribute spreading information that may support the elaboration of public policies that effectively promote health and well-being to children and adolescents.

\section{FUNDING}

Fundação de Amparo à Pesquisa do Estado de Minas Gerais - FAPEMIG (Foundation for Research Support of the State of Minas Gerais), Master's scholarship.

\section{ACKNOWLEDGMENTS}

All the authors contributed in the conception and planning of the project; gathering or analysis and interpretation of data; development or critical review of the content; and participation in the final approval of the final version of the manuscript.

\section{REFERENCES}

1. Mascarenhas MDM, Malta DC, Silva MMA, Lima CM, Carvalho MGO, Oliveira VLA. Violência contra a criança: revelando o perfil dos atendimentos em serviços de emergência, Brasil, 2006 e 2007. Cad Saúde Pública[Internet]. 2010[cited 2017 Feb 24];26(2):347-57. Available from: http://dx.doi.org/10.1590/S0102-311X2010000200013

2. World Health Organization - WHO. World report on violence and health [Internet]. 2002[cited 2017 Feb 24]. Available from: http://apps.who.int/iris/bitstream/10665/42495/1/9241545615_eng.pdf

3. Soares AL, Howe LD, Matijasevich A, Wehrmeister FC, Menezes AM, Gonçalves H. Adverse childhood experiences: prevalence and related factors in adolescents of a Brazilian birth cohort. Child Abuse Negl[Internet]. 2016 [cited 2017 Mar 2];51:21-30. Available from: https://www.ncbi.nlm.nih.gov/pmc/articles/PMC4710615/pdf/main.pdf

4. Brancaglioni BC, Fonseca RM. Intimate partner violence in adolescence: an analysis of gender and generation. Rev Bras Enferm[Internet]. 2016 [cited 2017 Mar 2];69(5):946-55. Available from: http://www.scielo.br/pdf/reben/v69n5/en_0034-7167-reben-69-05-0946.pdf

5. Organización Mundial de La Salud-OMS. Organización panamericana de la salud-OPAS. Prevención de la violência: la evidencia [Internet]. 2013[cited 2017 Mar 2];9-44. Available from: http://apps.who.int/iris/bitstream/10665/85671/1/9789275317488_spa.pdf

6. UNICEF. Situação Mundial da Criança: crianças em um mundo Urbano [Internet]. Brasília, DF: UNICEF; 2012 [cited 2017 Mar 2]. Available from: https://www.unicef.org/brazil/pt/PT-BR_SOWC_2012.pdf

7. UNICEF. Hidden in plain sight: a statistical analysis of violence against children [Internet]. New York: UNICEF; 2014 [cited 2017 Mar 2]. Available from: http://reliefweb.int/sites/reliefweb.int/files/resources/Hidden_in_plain_sight_statistical_analysis_EN_3_Sept_2014.pdf

8. Brasil. Ministério da Saúde. Estatuto da criança e do adolescente. 2a ed. Brasília: MS; 2003.

9. Brasil. Lei n. 13.010, de 26 de junho de 2014. Altera a Lei n. 8.069, de 13 de julho de 1990 (Estatuto da Criança e do Adolescente), para estabelecer o direito da criança e do adolescente de serem educados e cuidados sem o uso de castigos físicos ou de tratamento cruel ou degradante, e altera a Lei n. 9.394, de 20 de dezembro de 1996. Diário Oficial da União $2014 ; 27$ jun.

10. Lima R. Lei da Palmada: algumas considerações. Rev Esp Acad[Internet]. 2012[cited 2017 Mar 2];130:95-100. Available from: http://www.periodicos.uem.br/ojs/index.php/EspacoAcademico/article/download/16245/8831

11. Assis SG, Avanci JQ, Pesce RP, Pires TO, Gomes DL. Notificações de violência doméstica, sexual e outras violências contra crianças no Brasil. Ciênc Saúde Colet [Internet]. 2012[cited 2017 Feb 24];17(9):2305-17. Available from: http://www.scielo.br/ pdf/csc/v17n9/a12v17n9.pdf

12. Nunes AJ, Sales MCV. Violence against children in Brazilian scenery. Ciênc Saúde Colet[Internet]. 2016[cited 2017 Feb 24];21(3):871-80. 
Available from: http://www.scielo.br/pdf/csc/v21n3/en_1413-8123-csc-21-03-0871.pdf

13. Garbin CAS, Gomes AMP, Gattoa RCJ, Garbina AJI. Um estudo transversal sobre cinco anos de denúncia sobre violência contra crianças e adolescentes em Araçatuba, São Paulo. J Health Sci[Internet]. 2016 [cited 2017 Feb 2];18(4):273-7. Available from: http://www.pgsskroton.com.br/seer/index.php/JHealthSci/article/download/3293/3403

14. O ' Donnell M, Scott D, Stanley F. Child abuse and neglect: is it time for a public health approach? Aust N Z J Public Health[Internet]. 2008 [cited 2017 Mar 2];32(4):325-30. Available from: http://onlinelibrary.wiley.com/doi/10.1111/j.1753-6405.2008.00249.x/epdf

15. Oliveira HC, Pinto Jr EP, Tavares LT, Guimarães MAP, Oliveira MAD. Notificação compulsória de violência sexual contra crianças e adolescentes. Arq Ciênc Saúde [Internet]. 2015 [cited 2017 Jan 20];22(4)26-30. Available from: http://www.cienciasdasaude.famerp. br/index.php/racs/article/download/59/pdf_59

16. Justino LCL, Ferreira SRP, Nunes CB, Barbosa MAM, Gerk MAS, Freitas SLF. Violência sexual contra adolescentes: notificações nos Conselhos Tutelares, Campo Grande, Mato Grosso do Sul, Brasil. Rev Gaúcha Enferm[Internet]. 2011[cited 2017 Feb 24];32(4):781-7. Available from: http://www.scielo.br/pdf/rgenf/v32n4/v32n4a20.pdf

17. Sousa RP, Oliveira FB, Bezerra MLO, Leite ES, Maciel EJS. Caracterização dos maus-tratos contra a criança: avaliação das notificações compulsórias na Paraíba. Espaç Saúde [Internet]. 2015 [cited 2017 Mar 2];16(4):21-9. Available from: http://www. uel.br/revistas/uel/index.php/espacoparasaude/article/view/22408/5

18. Gawryszewski VP, Valencich DMO, Carnevalle CV, Marcopito LF. Child and adolescent abuse in the state of São Paulo, Brazil, 2009. AMB Rev Assoc Med Bras[Internet]. 2012 [cited 2017 Feb 24];58(6):659-65. Available from: http://www.scielo.br/pdf/ramb/ v58n6/en_v58n6a09.pdf

19. Fernandez CB, Tavares LF, Pinheiro MJS. Enfrentamento da violência sexual de crianças e adolescentes pelo legislativo no Amazonas. Argumentum[Internet]. 2016 [cited 2017 Mar 2];8(2):84-103. Available from: http://www.periodicos.ufes.br/ argumentum/article/view/11666/9950

20. Farias MS, Souza CS, Carneseca EC, Passos ADC, Vieira EM. Caracterização das notificações de violência em crianças no município de Ribeirão Preto, São Paulo, no período 2006-2008. Epidemiol Serv Saúde[Internet]. 2016 [cited 2017 Mar 2];25(4):799-806. Available from: http://www.scielo.br/pdf/ress/v25n4/2237-9622-ress-25-04-00799.pdf

21. Acosta DF, Amarijo CL, Silva CD, Gomes VLO, Cazeiro CC. Violência sexual: da denúncia à criminalização do agressor. Rev Enferm UERJ[Internet]. 2016 [cited 2017 Mar 2];24(2):e11518. Available from: http://dx.doi.org/10.12957/reuerj.2016.11518

22. Moreira TNF, Feuerwerker LCM, Schraiber LB. The foundation of care: Family Health Program teams dealing with domestic violence situations. Saúde Soc[Internet]. 2014 [cited 2016 Dec 2];23(3):814-27. Available from: http://www.scielo.br/pdf/sausoc/ v23n3/en_0104-1290-sausoc-23-3-0814.pdf

23. Frota MA, Lima LB, Oliveira MGP, Nobre CS, Couto CS, Noronha CV. Perspectiva materna acerca da repercussão da violência doméstica infantil no desenvolvimento humano. Enferm Cent O Min[Internet]. 2016 [cited 2017 Mar 2];6(2):2180-9. Available from: http://www.seer.ufsj.edu.br/index.php/recom/article/view/976/1101

24. Zambon MP, Jacintho ACA, Medeiro MM, Guglielminetti R, Marmo DB. Domestic violence against children and adolescents: a challenge. AMB Rev Assoc Med Bras [Internet]. 2012[cited 2017 Mar 2];58(4):465-4. Available from: http://www.scielo.br/pdf/ ramb/v58n4/en_v58n4a18.pdf

25. Mason F, Lodrick Z. Psychological consequences of sexual assault. Best Pract Res Clin Obstet Gynaecol[Internet]. 2013 [cited 2017 Mar 2];27(1):27-37. Available from: http://linkinghub.elsevier.com/retrieve/pii/S1521-6934(12)00137-X

26. Malta DC, Mascarenhas MDM, Neves ACM, Silva MA. Atendimentos por acidentes e violências na infância em serviços de emergências públicas. Cad Saúde Pública[Internet]. 2015[cited 2017 Feb 24];31(5):1095-5. Available from: http://www.scielo.br/ pdf/csp/v31n5/0102-311X-csp-31-5-1095.pdf

27. Waiselfisz JJ. Mapa da Violência 2012: crianças e adolescentes no Brasil [Internet]. Rio de Janeiro: Centro de Brasileiro de Estudos Latino-Americanos; 2012 [cited 2017 Feb 24]. Available from: http://www.mapadaviolencia.org.br/pdf2012/MapaViolencia2012 Criancas_e_Adolescentes.pdf

28. Morrison C, Gross B, Horst M, Bupp K, Rittenhouse K, Harnish C, et al. Under fire: gun violence is not just an urban problem. J Surg Res[Internet]. 2015 [cited 2016 Dec 2];199(1):190-6. Available from: http://linkinghub.elsevier.com/retrieve/pii/ S0022-4804(15)00399-6

29. Facuri CO, Fernandes AMS, Oliveira KD, Andrade TS, Azevedo RCS. Violência sexual: estudo descritivo sobre as vítimas e o atendimento em um serviço universitário de referência no Estado de São Paulo, Brasil. Cad Saúde Pública[Internet]. 2013 [cited 2017 Mar 2];29(5):889-98. Available from: http://www.scielo.br/pdf/csp/v29n5/08.pdf

30. Silva MCM, Brito AM, Araújo AL, Abath MB. Caracterização dos casos de violência física, psicológica, sexual e negligências notificados em Recife, Pernambuco, 2012. Epidemiol Serv Saúde[Internet]. 2013 [cited 2017 Mar 2];22(3):403-12. Available from: http://scielo.iec.pa.gov.br/pdf/ess/v22n3/v22n3a05.pdf

31. Fernandes APP, Mazza VA, Lenardt MH. Network of protection against childhood violence in light of the concepts of Capra. Rev Min Enferm[Internet]. 2013 [cited 2016 Dec 2];17(4):1032-7. Available from: http://www.reme.org.br/exportar-pdf/903/en v17n4a20.pdf 